\title{
Social And Environmental Responsibility Accounting Practices and Market Value Of Quoted Oil And Gas Firms In Nigeria
}

\author{
Eyo Victor Mfon ${ }^{1}$, Okafor Uchenna Israel ${ }^{2 *}$, Daferighe Emmanuel Emeakponuzo ${ }^{3}$ \\ 1. Department of Accounting, University of Uyo, Nigeria \\ 2. Department of Accounting, University of Uyo, Nigeria \\ 3. Department of Accounting, University of Uyo, Nigeria-PhD, accounting; 2018 World Champion on \\ Environmental Accounting \\ *E-mail of the Corresponding author: diamondhill4@yahoo.com
}

\begin{abstract}
Engaging in social and environmental activities as core components of CSR is rapidly growing as one of globally acceptable best practices for sustainability in business. Beyond their acclaimed societal benefits, the specific implication of social and environmental responsibility accounting practices (SERAP) on the economic performance of business entities is still a debate in many territories and industries. Therefore, the main objective in this study is to determine the nexus between SERAP and financial performance of quoted oil and gas firms in Nigeria. Whereas the measures of SERAP are environmental protection costs (EPC), community education and training costs (CETC), and community health related costs (CHRC), the proxy for financial performance is the market value of firms. Adopting ex post facto research design and modified Ohlson 1995 share price model, the general model demonstrated insignificant positive adjusted R-square. As all the P-values are not statistically significant, the unstandardised coefficients for EPC, CETC, and CHRC reveal a mix of positive and negative insignificant indices at varying extents. It was concluded that the level of SERAP by oil and gas firms in Nigeria did not significantly influence their capital market valuation. While the researcher further inferred that social and environmental public concerns rank as the primary responsibility of the government which receives taxes from business entities, oil and gas companies may cautiously engage in SERAP to avert financial losses through restiveness and agitations from some disgruntled stakeholders. More so, as ethical practices for promoting their going concern philosophy is mainly attainable within a wholesome planet and healthy people.

Keywords: Social and Environmental responsibility Accounting Practices (SERAP), environmental protection costs, community education and training costs, community health related costs, Capital Market performance, Value of Oil and Gas Companies.
\end{abstract}

DOI: $10.7176 / \mathrm{EJBM} / 13-12-07$

Publication date:June $30^{\text {th }} 2021$

\section{Introduction}

Social and Environmental Responsibility Accounting Practices (SERAP) is a description for all the accounting activities that promote and report the social and environmental obligations of business entities alongside their conventional economic activities. SERAP, also known as Sustainability Accounting Practices, Corporate Social Responsibility (CSR) disclosures, or Sustainability Reporting is mainly concerned with gathering, analyzing, recording, reporting, and interpreting the quantitative or qualitative statistics of social and environmental commitments of businesses.

However, many scholars have defined CSR from diverse dimensions. For instance, Ademosu (2008) described CSR as the contribution of organizations towards the social, economic, or/and environmental welfare of their host communities. In a related definition by World Business Council for Sustainable Development (1990), CSR is continuous commitment by business entities to be ethical and contribute towards economic development, besides improving the quality of life for their workforce and their families including other members of the local community. Aaronson (2003) defined CSR as business decision process in compliance to ethical or legal requirements in an effort towards social development and environmental sustainability. Moreover, economic, social and environmental management are the major corporate dimensions of the concept of CSR (VanMarrewijk 2003).

Therefore, SERAP tends to establish interdependencies between social and environmental risks in terms of costs and possible business opportunities. These practices are originally found within the domain of "not for profit organisations"; however, its emergence among profit-oriented organisations though not without some controversies is not only attracting worldwide attention but also creating a significance in the global economy. While this increasing interests in SERAP in the recent years may have resulted from globalization and complex international business activities accompanied by stakeholders' demands for 
enhanced corporate transparency and accountability (Jamali \& Mirshak 2007); the controversies may not be unconnected to the difficulties in measuring negative externalities arising from activities of corporate entities as well as the argument surrounding CSR's ability to contribute to the profit objective of business entities. SERAP also relate to the collating and communicating quantitative and/or qualitative financial data about an organization's interaction with the society in relation to the natural environment (Gray, Collison \& Bebbington 1998). Thus, Social and Environmental Responsibility Accounting Practices are the role of accounting in making the social and ecological impact of organization's activities more transparent to all stakeholders for due accountability and responsibility by such organisation.

The concept of social and environmental responsibility accounting practices and reporting include social welfare where a business entity is also responsible and accountable to stakeholders other than its shareholders. They include but not limited to activities such as: charitable donations and support for education, pollution prevention, health and safety of host communities, employment opportunity for host communities, and welfare of the employees. Others are community infrastructural projects, inclusive decision-making involving employees, environmental sustainability in every operation, and so on [Company and Allied Matters Acts (CAMA) 2004]. While it may be financially difficult to measure the impacts of some environmental and social activities, such as the indices of carbon emission on human life, the lung diseases and cancers resulting from pollution, the number of lives lost due to toxic gas leakage from a company's plant among others (Daferighe 2010); it seems economically important to study the influence of spending on such concerns on the performance of firms. Therefore, social and environmental responsibility accounting practices such as environmental protection cost and community health related cost are centrally aimed at encouraging varying extents of social inclusion and environmental considerations in organisations' activities and decision process; and at the same time creating opportunities that may improve the financial outlook of such entities. Moreover, the value of a firm is an important component of financial outlook in the assessment of potential investors.

The value of a firm (VF) is the fair amount which an investor will pay to acquire the ownership of a firm or a fraction of it in an arm's length transaction. Guleryuz (2009) asserted value of a firm to be the market value of a company's ownership as anticipated by independent buyers and sellers with adequate information about the entity which is free from any encumberance or lien. Therefore, VF is one of the key indicators for assessing the performance of firms for investment decisions. While VF has traditionally been attributed to some micro and macro-economic factors such as dividend, management, interest rate, socio-political environment, and so on, Mohammed and Samuel (2017) demonstrated that SERAP (through CSR) may be significant factor for ascertaining the value of a firm. Thus, an objective and adequate disclosure of CSR may be capable of attracting and winning the confidence of prospective investors. As ethical approach to investment is increasingly gaining worldwide attention and reflecting business best practices on a global scale, Abdullah, Merv and Ali (2018) also asserted that engaging in CSR and presenting them in a sustainability report is capable of improving the value of firms.

Lee, Seo and Sharma (2013) further posited that increase in CSR activities is capable of strengthening a company's market value through improved corporate reputation, thereby averting publicity cost and naturally winning the trust of the investors. Bird, Hall, Momentè and Reggiani (2007) contended that managers engaging in CSR practices do not only improve their business bottom line but also their capital market performance. This further implies that CSR activities of a company in aggregation is capable of enhancing their access to capital. The business implication is that CSR could improve the nexus between a company and its crucial business environment including banks, government agencies, and investors.

Nonetheless the relationship between SERAP and performance of firms, especially the market value of firms is still controversial and inconclusive across the globe. This is evidenced in a study by Dolores, María, María and Julio (2019) which highlighted that a number of findings about the link between CSR disclosure and performance have resulted to positive, neutral, or negative relationship. However, Moskowitz (1972) is among the foremost researchers who formally argued that socially responsible firms may perform better than conventional firms. Since then, the argument remains unresolved till date, despite many academic researches. While a study suggested a negative relationship between CSR and performance of financial institutions in Poland (Justyna, Beata \& Przemysław 2017), improvement in CSR actions revealed higher stock returns in a related study of Greek companies (Karagiorgos 2010); both in Eastern Europe. Whereas Fahria, Sahibzada and Abdul (2016) concluded a significant positive association between environmental reporting and share prices of manufacturing firms in the United States of America (U.S.A.); though positive, finding by Otuo and Abraham (2017) did not report significant association between CSR and access to finance among SMEs in Ghana. The researchers in Ghana contended that the positive relationship between the variables may in time improve financial performance, if CSR practices are consistently in place. Two contemporary studies in Nigeria and Kenya revealed significant relationship between expenditure on philanthropic engagement and profitability among Banks (Odetayo, Adeyemi \& Sajuyigbe 2014) and (Emily, Mwalati, Robert, Musiega \& Maniagi 2014). However, Folajin, Ibitoye and Dunsin (2014) differ though not totally in their finding that CSR expenses is 
of short-term negative implication on the net profit of United Bank for Africa but will provide better returns in the long run. In a study of oil and gas, manufacturing, and construction industries, Daferighe, Akpanuko and Offiong (2019) reported that investment in social activities has no significant positive relationship with return on equity (ROE) of quoted Companies in Nigeria. The dissenting opinions in the subject area could be attributed to subjectivity in engaging, measuring, and disclosing qualitative social and environmental information by firms across the world. For greater objectivity however, absolute costs (quantitative information) incurred and disclosed on relevant proxies for SERAP is adopted in this study.

These controversial findings are currently going on unabated across different countries and industries. Thus, raising more concern and questions among researchers. In unfairness to the dissenting global arguments about the cost-benefit effect of social and environmental practices by business entities, CSR researches in Nigeria seem to be dominated by studies in less environmentally and socially sensitive sectors, such as banking and general manufacturing with insignificant or no negative externalities. The results obtainable from such less-sensitive sectors could be less reliable for capital market decisions and may consistently yield statistically unreasonable outcomes that continuously distort a more generalizable conclusion in the subject area. Despite pollution through effluence by some oil and gas firms in Nigeria and the recurrent agitations by oil producing communities on issues of pollution, land degradation, and neglect by such firms, only less than commensurate research attention appears to be in place in their aspect of sustainability accounting. While ROA, ROE, and so on as adopted by many prior researchers may be reliable accounting measures of performance, firms' stock market reputation in terms of value may demonstrate greater significance for attracting more investors. Moreover, an assessment of corporate financial performance by capital market participants and other external stakeholders appear more reliable for decision making by all the external and some internal stakeholders.

Hence, the current objective of empirically investigating the nexus between social and environmental responsibility accounting practices (SERAP) and performance measured by value of quoted oil and gas firms in Nigeria. Whereas the determinants for SERAP in this study are absolute figures for environmental protection costs (EPC), community education and training costs (CETC), and community health related costs (CHRC) incurred in the CSR programmes of firms operating in the oil and gas sector, the proxy for measuring financial performance is the value of quoted firms in the sector.

\section{Literature Review and Hypotheses Development}

\subsection{Theoretical Background}

The intersect of stakeholder theory, Legitimacy theory, and agency theory appears to hold a reasonable explanation about the association that may exist between social and environmental responsibility accounting practices and performance of oil and gas firms; thus, adopted in this study.

\section{i. $\quad$ Stakeholder Theory}

Introduced in 1984 by Edward Freeman, stakeholder theory centers on individuals or organisations whose practices, policies, decisions, or goals may affect the well-being of each other (Ebiringa, Eme, Chigbu \& Obi 2013). Exponents of the theory posit that corporations exist for the benefit of other constituencies with indirect interest in the entity, in addition to their shareholders. In the opinion of Al-Amosh and Mansor (2018), It emphasizes the need for management to satisfy the aspirations and expectations of different stakeholders including transparent reporting while attempting to achieve organizational goals. Among others, the stakeholders may include but not limited to employees, suppliers, customers, investors, shareholders, host communities, the general public, and the government.

Stakeholder theorists emphasize that taking the well-being of all constituent groups into consideration is a better way to maximize overall firm performance, especially in an environmentally and socially sensitive sectors like oil and gas, and brewery. Whereas satisfying the interest of shareholders in compliance with standards and government regulations is traditionally the central focus of most businesses over the years, the concern of larger chunk of other stakeholders is still a subject of debate across the world. Thus, stakeholder theory furnishes a convincing argument in support of CSR and reporting same in the financial statements as possible basis for high quality business performance. Therefore, this argument underpins the relevance of stakeholder theory to the current research. The researcher opines that the quality of oil and gas firms' reputation on the basis of CSR practices may influence their market value.

Moreover, stakeholder theory enjoys the support of Triple Bottom Line (TBL) model of business reporting aimed at accommodating the expectations of emerging stakeholders. This model originated from John Elkington (1994) as a measure of sustainable business practices by preparing three segments of bottom lines (Slaper \& Hall 2011). The TBL also known as 3Ps raises concern for three factors; profit, people and planet. It aims at 
measuring performance (bottom line) along multidimensional

concept of sustainability reported after deducting economic, social, and environmental costs of operation.

\section{ii. Legitimacy theory}

This theory contends that business entities ensure to operate within the moral and ethical values of their respective societies. According to Suchman (1995), the theory aims at examining the extent to which society's value system is accommodated in the policy and value system of business organisations. This is also to ascertain the extent to which social expectations are part of various organisations' objectives. It therefore recommends that companies consistently ensure to operate within the norms of their host societies (Guthrie \& Parker 1989; Brown \& Deegan 1998; Reverte 2009), thus, providing a broader perspective of sustainability reporting.

Drawing from this theory, an organisation is expected to interact with the society via an implied social contract requiring them to engage in socially responsible and acceptable practices which is fundamental for their survival and success in the long range of time (Guthrie \& Parker 1989). Contrary organizational operations outside societal expectations is capable of impairing their capacity to obtain certain resources and support from their host society and the government (Oliver 1991). Oil and gas Organisations therefore may adopt social and environmental engagement and disclosures as part of their strategies for approaching community expectations in their practices (Deegan, Rankin \& Tobin 2002; Cho \& Patten 2007). In tandem with legitimacy theory, sustainability reporting seems an appropriate strategy for achieving societal acceptability (Ching \& Gerab 2017), thereby creating a positive public image for firms by enhancing their corporate reputation (Oliveira, Rodrigues \& Craig 2010).

\section{iii. Agency Theory}

Originated in the information economics literature, agency theory is a model of principal-agent relationship. The principal delegates responsibility and authority to the agent who acts on behalf of and in accountability to the principal (Eisenhardt 1988). It explains the interaction between shareholders as principals and managers as agents subject to an assumption of information asymmetry and conflict of interest between the parties (Jensen \& Meckling 1976; Eisenhardt 1989). To that extent, business entities are assumed a nexus of contracts between managers and shareholders, with managers possessing superior information than shareholders about the current and projected overall performance of the company (Ho \& Taylor 2013), hence, resulting to information asymmetry.

Adopting agency theory, one can argue that CSR disclosure also reduces information asymmetry between potential investors and firms' evaluation, which makes for more guided and accurate investment decision. Arguing further in favour of agency theory, Bowerman and Sharma (2016) asserted that disclosing and reporting CSR make managers more accountable and transparent in their position as agents to investors. Moreover, transparency reduces information asymmetry and uncertainty paving way for more accurate investment decisions. In fact, an improved transparency makes for a more accurate estimates of future financial outlook of a firm. It simply implies that investors can more accurately forecast the market share price of a given company (Cormier \& Magnan 2007). Therefore, reporting CSR may be value relevant to investors, if included among the mix of information in consideration for evaluating firms (Power 1991), subject to further investigation in the current study of quoted oil and gas firms in Nigeria.

\subsection{Empirical Literature}

Findings in prior Studies on social and environmental responsibility accounting practices (SERAP) and performance of companies across different industries in different territories is a mixed set of negative, positive, and neutral associations. While some researchers subject the relationship to firms' characteristics, governance attributes, and ownership structure (Al-Amosh \& Mansor 2018), other groups attribute it to type of industries, sectors, and institutions (Wang, Dou \& Jia 2016; Ioannou \& Serafeim 2010). However, Justyna, Beata and Przemysław (2017) argued that the relationship is stronger for firms in advanced economies than for those in developing economies.

Therefore, cascading this review from the developed countries to the developing ones, 93\%of the leading 100 Japanese firms and $91 \%$ of the leading 100 UK companies provided CSR disclosure (CSRD) as evidenced in a report by KPMG (2008). This, however suggest the apriori expectation of positive relationship to Bowerman and Sharma (2016) in their investigation of how corporate social responsibility disclosures influence the share prices of firms in japan and the United Kingdom (UK). The findings suggested more consideration of CSRD information in the mix of information used by investors in the UK for firm valuation during investment analysis, 
whereas investors in Japan did not seem to share in such sentiment. Moreover, the researchers adopted price specification Ohlson model (1995) for testing incremental effect of CSRD on share prices. A similar outcome to that of Bowerman and Sharma (2016) about the UK was also concluded by Marna, Charl and Chris (2015) who studied the effect of CSRD on share prices of companies in the UK. Coincidentally, Ohlson model (1995) was also used for testing incremental effect of CSRD on financial information's influence on share prices.

By adopting descriptive explanatory research design and secondary source of data, Fahria and Sahibzada (2016) examined the influence of environmental disclosures on the performances of manufacturing firms in the United States of America (USA)for 2015. Extracting data from selected companies published financial reports, CSR reports and Sustainability reports for the relevant year. However, Greenhouse Gas Emission, Water Consumption and Waste Disposal served as predictor variables, while Market Share served as determinant for performances of firms. Based on the critical review of literature and empirical investigation, the researchers concluded that the 3 independent factors are key indicators of environmental reporting which are influencing the operating performance of the surveyed firms. In the mixed results, findings about UK and USA are convergent in positive association between the variables, while that of Japan is indifferent about the relationship.

A review of other studies in Asia also demonstrated a controversial outcome. Dezhu, Shasha and Dongmin (2013) investigated the impact of energy-saving efforts on firm value, adopting carbon emission rights trading scheme (CERTS) of China as an exogenous shock. The researchers found that CERTS demonstrated incremental effect on the market value of energy related firms; Moreover, the energy-saving efforts of firms further influenced their market value and investors reaction. Wan, Mahmoud and Arkan (2014) set out their study in Malaysia to determine the effect of environment, marketplace, community, and workplace dimensions of CSR on corporate financial performance. In their content analysis of financial report from three firms listed on Bursa, Malaysia for 2007-2011, and subsequent regression analysis of hypothesis; It was discovered that Corporate Social Responsibility and Corporate Financial Performance relate positively.

Rahman, Jauhari and Roslan (2013) examined the association between environmental disclosures and financial performance of Listed Companies in Malaysia for 2009. In addition to environmental reporting as independent variable, return on assets (ROA) and return on equity (ROE) as dependent variables, and company size, leverage and industry sensitivity as control variables, content analysis was also adopted. While $68.1 \%$ of 299 companies reported environmental information in their financial statements, $18.3 \%$ of them disclosed that in a separate segment of the financial report. Moreover, environmental reporting and ROA demonstrated insignificant relationship, while environmental reporting and ROE were positively associated similar to leverage, company size, and industry sensitivity.

In a related investigation in Jordan, Bilal, Omar, and Omar (2016) examined the nexus between different dimensions of CSR and market value of companies listed on the Amman Stock Exchange (ASE) of Jordan for 2006-2010. The researchers disaggregated CSR dimensions into environmental, community, human resources, and products; and observed that community, environmental, and product activities resulted into decreasing effect on the market value of firms operating in food and beverage industry, while human resources activities did not influence the market value of companies in the same industry. Moreover, the communist dimension was negatively interacted with market value of firms in the pharmaceutical and medical industry, while the three other dimensions demonstrated no effect on market value in the same industry. The four dimensions did not also demonstrate any effect on market value of companies in the chemical industry.

Another study in Asia by Lawrence, Thomas and Yu (2017) investigated Sustainability Reporting and Value of Listed Companies in Singapore. The researchers utilized an established sustainability reporting assessment framework for ascertaining how adoption and quality of sustainability practices are connected with market value of firms. Findings revealed that sustainability disclosure is positively connected with market value of firms. However, the association was not connected to sectoral or ownership structure such as government-linked and family ownership.

African researchers in this subject area are not different in Their mix results of findings. In South Africa, Chetty, Naidoo and Seetharam (2014) investigated the impact of environmental reporting on corporate financial performance (CFP) from 2004-2013. The researchers examined the differences between short and long range effect of CSR activities on CFP of companies included in the Johannesburg Securities Exchange Socially Responsible Investment Index (JSESRI). Their findings revealed that CSR result to no significant 
differences in financial performances. Adopting regression analyses model however, CSR reports as the independent variable and Accounting-based measures - Return on Equity, Return on Assets, and Earnings per Share- and Market-based measures -risk and Market Capitalization as dependent variables.

In Nigeria, Akinlo and Iredele (2014) examined the impact of Corporate Environmental Disclosure (CED) on market value of fifty quoted companies. Adopting Tobin's q model for the measurement of the market value of firms, the researchers found that CED significantly and positively influenced market value of firms when aggregated, while waste management cost and cost of compliance with environmental laws, Environmental pollution and control policy negatively impacted on market value of firms. Businesses were however recommended to be cautious in areas with negative environmental impact on the value of the firm, but invest in areas that improve value for them.

Considering the threat to the growth of oil and gas industry in Nigeria due to militancy and other restiveness within Host communities, some firms in the industry engage in corporate social responsibilities to cater for certain needs of the people and the environment. Moreover, the influence of such expenses on the performance of business entities is still controversial; Thus, forms the main focus of a study by Adewoye, Olaoye and Ogundipe (2018). Adopting ex-post facto research design and fixed effect panel for data analyses, Breusch Pagan Lagrangian Multiplier (LM) and Hausman models were used for estimating the test result. Results showed a mixed isolated effect of ethical, environmental, and social responsibilities on performance. Moreover, the details of the results revealed F-ratio 3.109387 ( $\mathrm{P}$ value $=0.002652<0.1,0.05$ $\& 0.01$ levels of significance) as an indication of a significant positive nexus between corporate social responsibilities and performance of oil and gas companies in Nigeria. The study also recommended firms to review their expenditure items to accommodate CSR.

Researching on the comparative analysis of social responsibility reporting practices and the effect on performance with total assets of listed oil and gas companies and firms in the consumer goods sub-sector of the Nigerian economy including breweries, Akparhuere (2019) utilized ex-post facto research design. The secondary data were obtained from the annual financial reports of the sampled firms. Adopting correlation coefficient, coefficient of determination and simple regression analyses model through SPSS version 20.0, the researcher found that donations an gifts have significant effects on performance of both sets of firms. Thus, it was recommended that firms should consolidate on discretionary social responsibility practices as a strategy for warding off restiveness in their host communities. In a convergent study, Fodio, Abu-Abdissamad and Oba (2013) investigated the benefit of socially responsible activities in sustaining business ventures. Parsimonious regression model was adopted for ascertaining the impact of socially responsible activities on the market value of finance services in Nigeria for 2004-2008. The result revealed that Human Resource Management and Community Development have significant positive relationship with market value of finance services. Moreover, the researchers suggested that not all environmental investments may yield return in a finance form; some may be of key importance in stimulating competitive advantage and strategic value. This outcome further lends credence to an earlier finding by Adewoye, Olaoye and Ogundipe (2018).

Motivated by the claim of the stakeholders' theorist that Social Accounting practices positively influence economic performance of business organisations, Daferighe, Akpanuko and Offiong (2019) examined measures of social investment accounting, besides ascertaining the relationship between the investment and performance measured by Return on Equity (ROE) of quoted firms in Nigeria. Whereas descriptive research design was adopted, data for the regression were derived from financial reports covering 2009 to 2015, of purposively selected fifteen quoted firms in the Oil and Gas, Manufacturing, and Building and Construction sectors in Nigeria. Multiple regressions were conducted for four hypotheses. As findings, Social Accounting Practices variables (Education Programmes Cost (EPC) and Health Related Cost (HRC) showed insignificant positive relationship with return on equity (ROE), while Infrastructural Development Cost (IDC) revealed significant negative relationship with ROE of quoted firms in Nigeria. The researchers concluded that investment in social activities by quoted firms in Nigeria were not significantly and positively related with ROE. Thus, they recommended government which received taxes from companies to also be responsible for providing basic infrastructures for the society, while companies may within their financial capacity invest in education programmes and health care which could improve their economic benefits in the long-run. As an empirical demonstration of controversy in this subject area, these findings are in direct contrast with those of Akparhuere (2019) and Adewoye, Olaoye and Ogundipe (2018).

By using ex-post facto research design, Asuquo, Temitayo and Raphael (2018) investigated the influence of sustainability disclosure on performance of breweries in Nigeria. To achieve the objective, data were 
obtained from financial statements of the three breweries in focus for five years (2012-2016). Return on Asset (ROA) was the dependent variable whereas Economic Performance, Environmental Performance, and Social Performance disclosures constituted the independent variables. However, findings revealed that the independent variables did not have significant effect on return on asset of selected breweries in Nigeria.

A related empirical study by Okafor, Oji and Daferighe (2020) examined the effect of social investment cost (SIC) and environmental protection cost (EPC) on the financial performance of quoted cement companies in Nigeria. Sales turnover (ST) and market value of firms (MVF) respectively ranked as proxies for financial performance to develop two hypotheses. That suggests the use of ex-poste facto research design. Data were however obtained from relevant audited annual financial reports and Nigerian stock exchange factbooks for 2009-2017. In the multivariate regression result, H1 revealed a significant positive association between the predictor variables and ST. Similarly, an insignificant, though positive nexus was observed between the predictor variables and MVF in the test of $\mathrm{H} 2$. Observing a low level of such practices, the researchers remarked that if such low level and inconsistent environmental and social accounting practices (ESAP) could influence financial performance of cement companies in Nigeria, increase in ESAP therefore holds greater promise for the cement industry. Hence, they recommended cement companies to adopt ethical approach towards expanding investment in ESAP.

In contrast to the finding by Asuquo, Temitayo and Raphael (2018); but in convergence to Okafor, Oji and Daferighe (2020), another related study by Adesunloro, Udeh and Abiahu (2019) made use of Descriptive research design to ascertain the extent of effect of CSR disclosure on performance of Nigerian Breweries Plc. The researchers adopted content analysis and survey research designs. Content analysis was for extracting data from the annual financial reports of Nigerian Breweries Plc in comparism with three selected Nigerian banks, while questionnaire was for obtaining information concerning the effect of CSR reporting on firms' performance. T-test statistics was used for data analyses at 5\% level of significance. Findings showed that Nigerian Breweries Plc did not significantly disclose its CSR accounting information in their 2014-2017 annual reports in comparison to the three surveyed banks in Nigeria. Nevertheless, the available and insignificant CSR reports of Nigerian Breweries Plc improved their financial performance. By implication, the outcome means that the performance of Nigerian Breweries Plc is positively influenced by its CSR culture. The researchers therefore recommended Nigerian Breweries Plc and other manufacturing companies to be intentional about improving their stakeholders investment through adequate disclosure of CSR.

Utilising ordinary least square and logistic regression analysis, Oba (2012) examined the impact of Community Social Responsibility, Charitable Contribution, and Human Resource Management on the market value of quoted conglomerates as measured by Tobin'sQ. However, the researcher observed a significant positive nexus between environmental responsibility and financial performance, vice versa. Similarly, Olaroyeke and Tabitha (2015) examined the effects of Corporate Social Responsibility on performance of manufacturing companies in Nigeria. Generating primary data through questionnaire and using descriptive statistics for analyses, the researchers found that some Manufacturing firms involve in CSR not only for immediate profit motive but also for other reasons such as good reputation, marketing and advertising strategy, among others.

Probing further into the association between CSR and firms' performance, lya, Badiga and Faiza (2015) investigated the impact of CSR expenditure on the performance of First Bank Nigeria Plc with profit after tax from 2001 to 2014 as proxy for performance. Adopting Ordinary Least Square, the researchers discovered that increase in CSR expenditure raised the performance of First Bank Nigeria Plc. In a similar study, Folajin, Ibitoye and Dunsin (2014) investigated the impact of CSR on the performance of United Bank for Africa (UBA) Plc with profit after tax for 2006-2012 as measure of performance. Also adopting ordinary Least Square regression for the analyses of data relating to cost on Corporate Social Responsibility and profitability, it was found that expenditure on CSR was inversely related with Net Profit in the short-term but expected to improve returns in the long range of time.

In another dimension, Osazuwa, Francis and Izedonmi (2013) examined how corporate attributes impact the environmental disclosure of one hundred listed firms in Nigeria. using descriptive statistics, and Binary probit regression analysis, it was observed that performance of the firms (profitability) and the industry type had a significant influence on environmental disclosure. Moreover, the size of a firm may rank as an intervening variable in this relationship between SERAP and performance of firms. Unerman and O'Dwyer (2007) asserted that social and environmental responsibility accounting practices are optimally adopted by most multinational companies; and that maximizing stockholders value by other business entities requires engaging in the best voluntary practices of social and environmental responsibility accounting. 
Moreover, a significant number of prior studies in this subject area reported positive nexus between size of a firm and the extent of SERAP (Hossain \& Reaz 2007; Branco \& Rodrigues 2008; Siregar \& Bachtiar 2010; Nazari, Herremans \& Warsame 2015). Such relationship is supported by an earlier assertion of the agency theory that large firms are liable to high agency costs resulting from information asymmetry between shareholders and managers (Jensen \& Meckling 1976). Thus, large firms are likely to report more information than small firms as a strategy for reducing agency cost. The underlying reason may be to narrow the information asymmetry which often exist between shareholders and managers, in addition to positioning to enjoy greater legitimacy from the society. Large firms probably would lose more patronage and other goodwill in the event of impaired legitimacy than small firms, which might consequently result to higher political costs (Shamil, Shaikh, Ho \& Krishnan 2014). Besides, large companies might have more developed information systems (Uyar \& Kılıç 2012) for an easy compliance with the GRI-based reporting. To such extent, most oil and gas firms in Nigeria rank among large firms. Thus, expected to significantly engage in social and environmental accounting practices adequate to demonstrate a reliable trend with value of firms.

\subsection{Gap in the Literature}

Prior researchers are almost convergent about the inconsistencies and controversies that characterize findings in this subject area, such simply raises more questions and rationale for further studies. Unfortunately, related studies in Nigeria seem to be dominated by studies in less environmentally and socially sensitive sectors, such as banking and general manufacturing with insignificant or no negative externalities. While results obtained from such less-sensitive sectors could be less reliable for capital market decisions and may consistently yield statistically unreasonable outcomes that continuously distort a more generalizable conclusion in the subject area, the current study however emphasizes on oil and gas firms operating in Nigeria. The purpose for choosing this sector is to examine the effect of SERAP on the market value of firms with significant social and environmental risks.

Moreover, since all financial performance are targeted at increasing shareholders' wealth, market valuation measurement appears more important to most potential investors and other members of the public who may not possess the skill to interpret accounting measurement indicators. So, the researcher's literature review emphasizes more on the effect of social and environmental accounting practices towards improving the capital market model of performance than on the accounting model of performance. Nonetheless sharing similar determinant variables with some reviewed researches, this study is significantly divergent in terms of choice of sector, measure of performance, or proxies for social and environmental responsibility accounting practices.

\subsection{Hypotheses Development}

In congruence with popular apriori expectation underlying the reviewed literature, the researchers formulated the following hypotheses:

$\mathrm{Ho}_{1}$ : There is no significant relationship between environmental protection costs and market value of quoted oil and gas firms in Nigeria.

$\mathrm{Ho}_{2}$ : Community education and training Costs is not significantly related to market value of quoted oil and gas firms in Nigeria.

$\mathrm{Ho}_{3}$ : There is no significant relationship between community Health related costs and market value of quoted oil and gas firms in Nigeria.

Ho4: environmental protection costs, community education and training Costs, community health related costs are not significantly associated to market value of quoted oil and gas firms in Nigeria.

\section{Operational Method}

\subsection{Research Design}

Ex post facto Survey research design is adopted in this study. Such survey appears most appropriate procedure for achieving the research objective, Since annual reports of companies are historical documents. Moreover, the population of this study consists of twelve (12) oil and gas firms quoted on the Nigerian Stock Exchange (NSE) as at January, 2021. Meanwhile, the list of the firms is contained in Appendix 1.

Considering the small size of the population, complete enumeration survey or census is applied. While only five (5) out of the surveyed companies satisfied the data requirement for this investigation, others were eliminated from the study. To compensate for the small size of sampled firms, the time series covered in the research is 
increased from initial 7years (2012-2018) to 12years (2007-2018). However, the selected sampled firms are Forte Oil Plc, Mrs Oil Nigeria Plc., Oando Plc, 11 Plc (Mobil), and Total Nigeria Plc.

The absolute figures for environmental protection costs (EPC), community education and training costs (CETC), and community health related costs (CHRC) in the CSR programmes of quoted oil and gas firms in Nigeria are the determinants for SERAP indices in this study. Whereas EPC was adapted from Okafor, Oji and Daferighe (2020), CETC and CHRC were adapted from Daferighe, Akpanuko and Offiong (2019). Specifically, data for the determinants were obtained from audited financial reports of relevant oil and gas companies. Moreover, a number of attributes have been previously adopted by researchers as a measure of performance. These include but not limited to return on asset (ROA), profit margin, return on capital employed (ROCE), and return on equity (Lee et al. 2013), in addition to value of firms (. Nonetheless, the market value of quoted firms is adopted as the proxy for performance in the current study. This is because such measure appears reliable for the evaluation of firms by external stakeholders, especially the investors. Thus, modified Ohlson price model 1995 as used by Marna, Charl and Chris (2015) and Bowerman and Sharma (2016) is specifically adapted for estimating the market value of firms across 12years (2007-2018). However, data for computing such estimation were obtained from Nigerian Stock Exchange (NSE) factbooks and all empirical tests are conducted at 5\% level of significance.

\subsection{Theoretical Specification of Model}

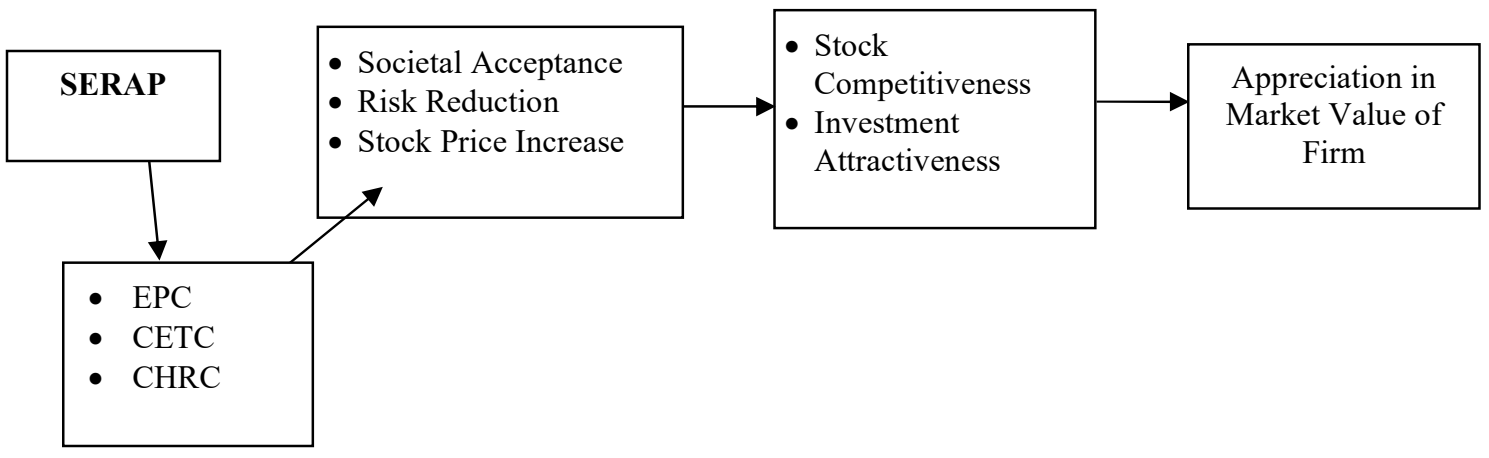

Figure 3.1 Social and Environmental Responsibility Accounting Practices Performance Model

Source: Researcher's Design (2021)

Environmental Protection Costs (EPC), Community Education and Training Costs (CETC), and Community Health Related Costs (CHRC) are the proxies for social and environmental responsibility accounting practices (SERAP). The popular belief among many researchers is that SERAP is positively associated with stock competitiveness through operating risk reduction, stock price increase, societal acceptance, and strategic longterm cost decrease. As such, it is also expected to attract investors and further increase the market value of firms.

\subsection{Empirical Specification of Model}

The model for this study is market value of firm (MVF) as obtained through Ohlson 1995 share price model. Moreover, the model has been widely adopted in several capital market-based accounting researches (Barth \& Clinch 2009).

The formula for the model is:

$\mathrm{MVE}_{t}=\alpha_{0} \mathrm{BVE}_{t}+\alpha_{1} \mathrm{AEE}_{t}+\alpha_{2} \mathrm{~V}_{t} \quad 3.1$

Where:

$\mathrm{MVE}_{t}$ is the market value of equity at time (t)

$\mathrm{BVE}_{t}$ is the book value of equity at time $(\mathrm{t})$

$\mathrm{AEE}_{t}$ is abnormal earnings from equity for the period ending time $(\mathrm{t})$.

It is calculated as the difference between net income for period $(\mathrm{t})$ and opening book value of equity multiplied by the required rate of return.

$\mathrm{v} t$ is other value-relevant information at time (t) (e.g. social and environmental responsibility accounting practices as proxies for other value relevant information in this study).

$\alpha_{0}, \alpha_{1}$ and $\alpha_{2}$ are coefficients of BVE, AEE and other value-relevant information at time $(\mathrm{t})$.

however, the model as modified and used by Marna, et al. (2015) and Bowerman and Sharma (2016) is adapted in this study as: 
Where:

$P_{i, t}$ : The dependent variable and a measure of the market prices for shares of company $(i)$ at time $(t)$.

The last day of the accounting period will be adopted as the proxy for $t$ in this model.

$\beta_{0}$ : constant variable.

$\beta_{1}$ and $\beta_{2}$ : coefficients of book value of share and earnings per share of company $(i)$ at time $(t)$.

$B V_{i, t}$ : the closing book value of equity per share for company $(i)$ at time $(\mathrm{t})$. It is calculated as difference between the company's total assets and total liabilities (including preference shares) divided by the number of outstanding shares at the end of the company's financial year, $(t)$.

$E_{i, t}$ : a measure of the earnings per share for company ( $i$ at time $(t)$. It is calculated as net profit after preference shares dividend divided by the number of outstanding shares at the end of the accounting year $(t)$.

$\varepsilon i, t$ : error term for company $(i)$ at time $(t)$.

Since the central aim in this study is to evaluate the association between share prices and SERAP as disclosed by quoted oil and gas firms in Nigeria, social and environmental expenditure indices are incorporated into equation (3.2) to develop equation (3.3). This is to expand the robustness of the test and for ultimately evaluating the value relevant of SERAP towards the market price of equity. Therefore, equation (3.3) is a multiple regression model for assessing the joint and isolated influences of SERAP variables on the market value of firms and the formula is stated as:

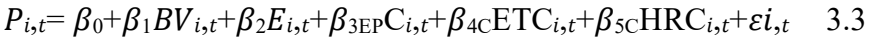

Where:

$\mathrm{EPC}_{i}, t$ : the absolute figure of environmental protection cost of company $(i)$ at time $(t)$.

CETC $_{i, t}$ : the absolute figure of community education and training cost of company $(i)$ at time $(t)$.

$\mathrm{CHRC}_{i, t}$ : the absolute figure of community health related cost for company $(i)$ at time $(t)$.

$\beta_{3}, \beta_{4}, \beta_{5}$ : coefficients of EPC, CETC, and CHRC respectively.

Other denotations remain as previously defined in equation (3.2).

\section{Data Analyses and Interpretation Of Results}

\subsection{Descriptive Statistics and Data Presentation}

Table 4.1 in Appendix II is the summary of panel data for the analyses. After the list of oil and gas companies in the investigations as shown in column 1, column 2 indicates the scope of the research in terms of the relevant years. While column 3 contains the closing book value (BV) of equity per share of the companies, column 4 is their measure of earnings per share. Columns 5, 6, and 7 are respective SERAP scores for EPC, CETC, and CHRC. Lastly, column 8 is a measure of the market prices (P) for shares of the oil and gas firms. The mean scores of the variables are further summarized in Table 4.2.

Table 4.2 Mean Statistics

\begin{tabular}{llll} 
Mean Statistics & & & \\
\hline P & Mean & Std. Deviation & $N$ \\
CHRC & 117.1227 & 90.48150 & 60 \\
CTEC & 5026503.7833 & 13469583.32639 & 60 \\
EPC & 17458679.1833 & 42710091.23262 & 60 \\
BV & 23871800.6333 & 68531864.84096 & 60 \\
E & 41.0803 & 27.01998 & 60 \\
\hline
\end{tabular}

Source: SPSS Test Result, 2021 
Table 4.3 Estimate of the Relationship between EPC, CETC, CHRC and P

$\begin{array}{ccccc}\text { Unstandardized } & \text { Standardized } & 95.0 \% \text { Confidence } & & \text { Collinearity } \\ \text { Coefficients } & \text { Coefficients } & \text { Interval for B } & \text { Correlations } & \text { Statistics }\end{array}$

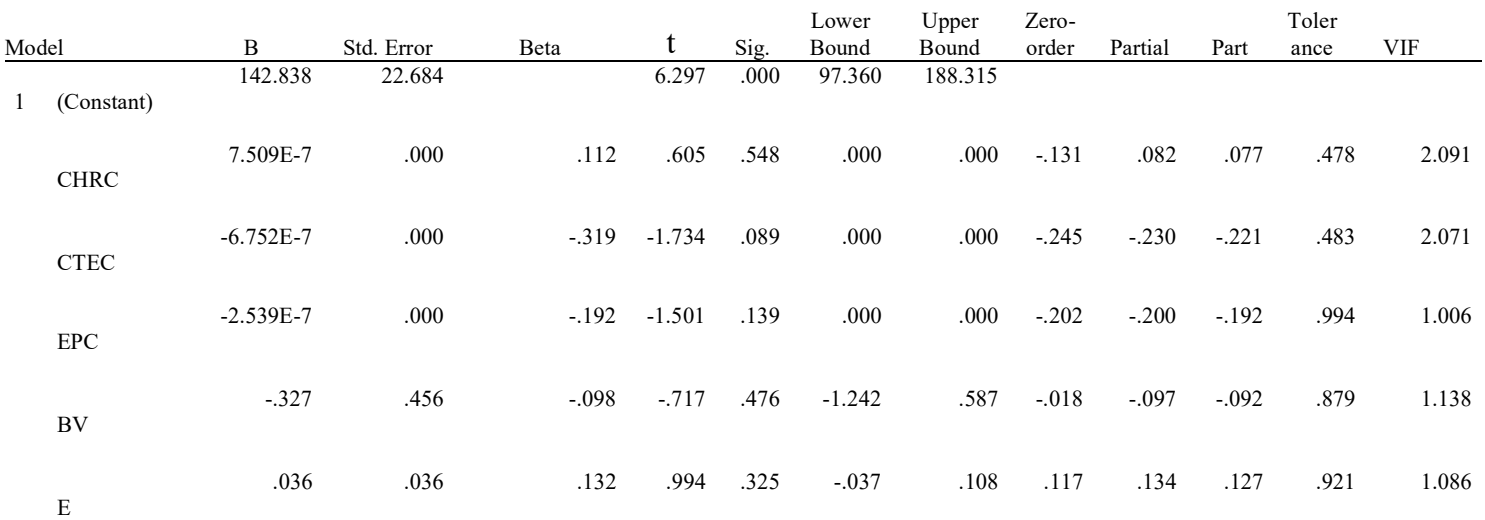

a. Dependent Variable: $P$

Source: SPSS Test Result, 2021

There are two segments in the analyses. The first segment is the specific tests of $\mathrm{HO} 1$ to HO3, the effect of EPC, CETC, and CHRC on the market value of quoted firms in the oil and gas industry of Nigeria). The second segment tests the possible multiplicative influence of EPC, CETC, and CHRC (HO4) on the market value of the companies.

Derivative of the Regression Equation

$\mathrm{P}=142.838+-0.327 \mathrm{BV}+0.036 \mathrm{E}+-0.0000002539 \mathrm{EPC}+-0.0000006752 \mathrm{CETC}+0.0000007509 \mathrm{CHRC}$

Test of Hypothesis One

$\mathrm{Ho}_{1:} \quad$ There is no significant relationship between environmental protection costs and market value of quoted oil and gas firms in Nigeria.

Table 4.3 reveals that a unit change in EPC with other variables held constant results into -0.0000002539 ($0.00002539 \%)$ shift in the value of oil and gas companies in Nigeria. Such implies insignificant inverse or negative association between the variables. The table also indicated that the sig. (P-value) of 0.139 for the variable is greater than 0.05 and the calculated T-value of -1.501 less than the tabulated value of 2.009 . Thus, the null hypothesis 1 is accepted.

\section{Test of Hypothesis Two}

$\mathrm{Ho}_{2}$ : community education and training Costs is not significantly related to market value of quoted oil and gas firms in Nigeria.

A unit change in CETC with other variables held constant demonstrates $-0.0000006752(-0.00006752 \%)$ variation in the value of the firms, as shown in table 4.3. This is also insignificant inverse or negative relationship between the variables. In tandem with this outcome, the calculated sig. (P-value) and T-value of 
0.089 and -1.734 are not respectively significant at greater than 0.05 and less than 2.009 tabulated $t$ in the same table. Hence, the null hypothesis 2 is also accepted.

\section{Test of Hypothesis Three}

Ho3: $\quad$ There is no significant relationship between community Health related costs and market value of quoted oil and gas firms in Nigeria.

A unit variation in CHRC with other variables held constant results to a corresponding change of 0.0000007509 $(0.00007509 \%)$ in the value of oil and gas firms in Nigeria, as indicated in table 4.3. Although a positive nexus between the variables, it is an insignificant or weak one. In contrast however, the calculated sig (P-value) and Tvalue of 0.548 and 0.605 are respectively greater than and less than 0.05 level of significance and tabulated $\mathrm{T}$ of 2.009. Therefore, null hypothesis 3 is also accepted.

Table 4.4 Model Summary

Model Summary

\section{Change Statistics}

\begin{tabular}{llllllllll}
\multicolumn{1}{c}{ Adjusted R } & Std. Error of R & Square \\
R & R Square & Square & the Estimate & Change & F Change & df1 & df2 & Sig. F Change \\
\hline $.345^{\mathrm{a}}$ & .119 & .038 & 88.75488 & .119 & 1.464 & 5 & 54 & .217 \\
\hline
\end{tabular}

Source: SPSS Test Result, 2021

Table 4.5 Analysis of Variance

\begin{tabular}{|c|c|c|c|c|c|c|}
\hline Model & & Sum of Squares & $d f$ & Mean Square & $F$ & Sig. \\
\hline \multirow[t]{3}{*}{1} & Regression & 57646.076 & 5 & 11529.215 & 1.464 & $.217^{\mathrm{b}}$ \\
\hline & Residual & 425381.166 & 54 & 7877.429 & & \\
\hline & Total & 483027.243 & 59 & & & \\
\hline
\end{tabular}

Source: SPSS Test Result, 2021

Test of Hypothesis Four- the General Model

Ho4: environmental protection costs, community education and training Costs, community health related costs are not significantly associated to market value of quoted oil and gas firms in Nigeria.

Table 4.4 reveals an adjusted R-square of $3.8 \%$ as the multiplicative influence of EPC, CETC, and CHRC on market value $(\mathrm{P})$ of oil and gas companies in Nigeria. Although positive, the joint contribution is a weak and insignificant one. Such weakness is further confirmed in table 4.5 by a calculated sig F (P-value) of 0.217 , which is greater than 0.05 level of significance and calculated F-value of 1.464, which is less than the critical F of 2.40. Hence, implies that social and environmental responsibility accounting practices (SERAP) did not influence the market value of oil and gas companies in Nigeria. Moreover, the appropriateness and adequacy of the model was further supported by variance inflation factor of less than 10 for all the variables in Table 4.3. Thus, indicating the absence of multicollinearity in the analysis.

\section{Discussion of the Findings}

Despite the popular apriori expectation of positive nexus between SERAP and financial performance, the insignificant outcome of this study may not be a surprising phenomenon to a number of academics and industry practitioners. While the consciousness of social and environmental sustainability is rapidly on the increase across countries and industries, its extent of implementation is relatively dependent on some factors. Nature of industry, 
regional and national bandwagon effect, economic development, predominant psyche among investors, and personal orientation rank among some of such factors. Perhaps, this research outcome is a practical demonstration of an earlier recommendation by Elena, Lijuan and David (2017) supported by Dolores, María, María and Julio (2019) that stratifying and measuring CSP within specific constraints of sectors, geographical regions, types of disclosures, and different thresholds of organizations' sizes is necessary for objective, reliable, and comparable association with corporate financial performance (CFP).

While the acceptance of null hypothesis across the three hypotheses and their insignificant multiplicative adjusted R-square of 3.8\% are in dissonance with some reviewed studies, it is not an isolated case but an iceberg phenomenon among similar research outcomes. Whereas the findings are divergent with those of Fahria et al. (2016) in USA, Lawrence et al. (2017) in Singapore, Adewoye et al. (2018) in Nigeria, they are in synchrony with those of Bowerman and Sharma (2016) about investors in Japan, Asuquo et al. (2018) in Nigeria, among others. In specific terms, Bowerman and Sharma (2016) reported that Japanese investors did not seem to consider CSRD among value-relevant information for firm valuation during investment analysis. Perhaps, oil and gas investors in Nigeria rank in the same class with investors in Japan.

Nonetheless, the extent of positive insignificant unstandardized coefficient contribution from CHRC to value of oil and gas firms is greater than the extent of negative insignificant unstandardized coefficient contributions from EPC and CETC to value of the firms. While CHRC contributed $0.00007509 \%$, EPC and CETC contributed $0.00002539 \%$ and $-0.00006752 \%$ respectively. Whereas more of CHRC appears promising for better financial performance, the aggregate result may further suggest that the overall level of social and environmental responsibility accounting practices (SERAP) is also insignificant or poorly strategic among oil and gas companies in Nigeria to influence investors decision. Therefore, the companies may need to engage in more SERAP for better capital market valuation.

The unstandardized coefficients for book value (BV) and earnings per share (E) of the oil and gas companies in Nigeria, which rank as control variables in this context are also negatively and positively insignificant in nexus with value of firm. This outcome is in variance with estant tutorial literature and apriori expectation. With other variables held constant, BV contributed a coefficient of $-32.7 \%$ while E contributed $3.6 \%$. Moreover, both their P-values and T-statistics are insignificant in the model. However, such result could be attributable to price fluctuation, size of oil and gas reserves, OPEC quota system, and so on that characterized the industry. Thus, the general risk of investment in the industry is highly variable besides streaks of conflict with disgruntled stakeholders.

\section{Conclusion and Recommendations}

\subsection{Conclusion}

The researcher concluded that the level of social and environmental responsibility accounting practices (SERAP) by oil and gas firms in Nigeria did not significantly influence their capital market valuation. In other words, changes in the level of SERAP was not adequate for predicting variations in market value of the companies. The outcome lends empirical credibility to the argument by exponents of stockholder theory that SERAP is a philanthropic action and the responsibility of the government, which could be harmful to the performance of companies by distorting optimal resource allocation (Lee, et al. 2013).

Drawing from the explanatory power of legitimacy and stakeholder theories however, the value-relevance of SERAP may rank as win-win situation for oil and gas companies in Nigeria. Its insignificant association with value of firms may still encourage CSR programmes and disclosure in the annual reports at least to assuage some disgruntled and aggrieved stakeholders to stop destroying property, disrupting operations, and wasting resources of firms in such sector. Since many business entities operating in this sector are already incurring different unaccountable costs and losses through unidentifiable agitators and militants, their management may see economic reasons to embrace SERAP as cheaper and better cost than wastage of resources to agitators and vandals. Moreover, such decision may become a cost reduction strategy and value relevant for wooing risk averse investors through stable and uninterrupted business operation with little or no loss due to restiveness. To this extent, expenditure in SERAP may assume a new status as investment with long-term potential for better capital market valuation.

Furthermore, oil and gas companies may also engage in corporate sustainability practices as ethical approach to sustaining wholesome earth and healthy people (active and potential customers) for achieving their 'going concern' objective. Implication of the findings however suggest the companies to be financially cautious if must engage in SERAP as the government that imposes and collects taxes from companies is mainly expected to 
brace up to the full responsibility of providing environmental protection, community education and training programmes, and community health needs for those negatively affected by adverse externalities of oil and gas activities.

6.2 Recommendations

Against the foregoing backdrop, the researcher recommends that:

i. Companies should be financially cautious and protect the interest of stockholders, if they must engage in SERAP for any reason.

ii. Beyond the short-term corporate financial performance, the 'going concern' philosophy of oil and gas firms is mainly attainable within a wholesome planet and healthy people. Hence, ethical approach to SERAP is recommended as crucial for their long-term survival and capital market performance.

iii. Oil and gas firms should strategically ward off possible agitations and restiveness by enlisting the legitimacy of major stakeholders through SERAP.

iv. The public awareness of SERAP and the related value relevance is still low among capital market investors in Nigeria, oil and gas companies may therefore continue with such practices as the associated benefit may be increasingly gradual.

\section{References}

Aaronson, S 2003, 'Corporate responsibility in the global village: The British role model and the American laggard', Business and Society Review, vol. 108, no. 3, pp. 309-318.

Abdullah, S, Merv, K \& Ali, U 2018, 'Sustainability reporting in the aviation industry: Worldwide evidence', Sustainability Accounting, Management and Policy Journal, vol. 9, no. 4, pp. 362-391.

Ademosu, E 2008, 'Corporate social responsibility: The experience of the Nigeria banking system', viewed 11 February 2021, <http:/www.acamb.com>

Adesunloro, B, Udeh, F \& Abiahu, M 2019), 'Corporate social responsibility reporting and financial performance: A study of Nigerian breweries plc', Archives of Business Research, vol. 7, no. 4, pp. 45-57.

Adewoye, J, Olaoye, C \& Ogundipe, A 2018, 'Corporate social responsibility and performance of oil and gas industry in Nigeria', EKSU Journal of the Management Scientists, vol. 2, no. 1, pp. 97-106.

Akinlo, O \& Iredele, O 2014, 'Corporate environmental disclosures and market value of quoted companies in Nigeria', The Business \& Management Review, vol. 5, no. 3, pp. 171-184.

Akparhuere, G 2019, 'Environment reporting in annual reports: A comparative analysis of reporting practices of listed firms in Nigeria', Archives of Business Research, vol. 7, no. 2, pp. 183-206.

Al-Amosh, H \& Mansor, N 2018, 'Sustainability and corporate reporting: A review on environmental and social accounting disclosure: A conceptual paper', International Journal of Accounting, Finance and Business, vol. 3, no. 8, pp. 78-87.

Asuquo, A, Temitayo, D \& Raphael, O 2018, 'The effect of sustainability reporting on corporate performance of selected quoted brewery firms in Nigeria', International Journal of Business \& Law Research, vol. 6, no. 3, pp. 1-10.

Barth, M \& Clinch, G 2009, 'Scale effects in capital markets-based accounting research', Journal of Business Finance \& Accounting, vol. 36, no. 3/4, pp. 253- 288.

Bilal, F, Omar, N \& Omar, Z 2016, 'Corporate social responsibility and market value: evidence from Jordan', Journal of Financial Reporting and Accounting, vol. 14, no. 1, pp. 122-135.

Bird, R, Hall, A, Momentè, F \& Reggiani, F 2007, 'What corporate social responsibility activities are valued by the market?', Journal of Business Ethics, vol. 76, 189-206.

Bowerman, S \& Sharma, U 2016, 'The effect of corporate social responsibility disclosures on share prices in Japan and the UK', Corporate Ownership Control, vol. 13, no. 2, pp. 202-216.

Branco, M \& Rodrigues, L 2008, 'Social responsibility disclosure: a study of proxies for the public visibility of Portuguese banks', The British Accounting Review, vol. 40, no. 2, pp. 161-181.

Brown, N \& Deegan, C 1998, 'The public disclosure of environmental performance information: a dual test of media agenda setting theory and legitimacy theory', Accounting and Business Research, vol. 29, no. 1, pp. 21-41.

Chetty, S, Naidoo, R \& Seetharam, Y 2015, 'The impact of corporate social responsibility on firms' financial performance in South Africa’, Contemporary Economics, vol. 9, no. 2, pp. 193-214. 
Ching, H \& Gerab, F 2017, 'Sustainability reports in Brazil through the lens of signaling, legitimacy and stakeholder theories', Social Responsibility Journal, vol. 13, no. 1, pp. 95-110.

Cho, C \& Patten, D 2007, 'The role of environmental disclosures as tools of legitimacy theory: A research note', Accounting, Organizations and Society, vol. 32, no. 7/8, pp. 639-647.

Companies and Allied Matters Acts (CAMA), 2004: With Companies Proceeding Rules, Companies WindingUp Rules 2001, Company Regulation 2012 and Investment and Securities Act 2007, p. 884.

Cormier, D \& Magnan, M 2007 'The revisited contribution of environmental reporting to investors' valuation of a firm's earnings: An international perspective', Ecological Economics, vol. 62, no. 3, pp. 613-626.

Daferighe, E, Akpanuko, E \& Offiong, P 2019, 'Social accounting practices and profitability of companies in Nigeria', Archives of Business Research, vol. 7, no. 6, pp. 233-246.

Daferighe, E 2010, 'Environmental accounting and degradation', A Quarterly Journal of Association of National Accountants of Nigeria, vol. 18, no. 4, pp. 55-65.

Deegan, C, Rankin, M \& Tobin, J 2002, 'An examination of the corporate social and environmental disclosures of BHP from 1983-1997: A test of legitimacy theory’, Accounting, Auditing \& Accountability Journal, vol. 15, no. 3, pp. 312-343.

Dezhu, Y, Shasha, L \& Dongmin, K 2013, 'Do efforts on energy saving enhance firm values? Evidence from China's stock market', Elsevier, vol. 40, pp. 360-369.

Dolores, G, María, J, María, L \& Julio, S 2019, 'Corporate Social Responsibility Disclosure and Performance: A Meta-Analytic Approach', Sustainability Journal, vol. 11, no. 4, pp. 1-33.

Ebiringa, O, Emeh, Y, Chigbu, E \& Obi, J 2013, 'Effect of firm size and profitability on corporate social disclosures: the Nigerian oil and gas sector in focus', British Journal of Economics, Management \& Trade, vol. 3, no. 4, pp. 563-574.

Eisenhardt, K 1988, 'Agency and institutional theory explanations: The case of retail sales compensation', Academy of Management Journal, vol. 31, no. 3, pp. 488-511.

Eisenhardt, K 1989, 'Agency theory: An assessment and review;m Academy of Management Review, vol. 4, no. 1, pp. 57-74.

Elena, M, Lijuan, Z \& David, C 2017, 'Issues in sustainability accounting reporting', Accounting and Finance Research, vol. 6, no. 3, pp. 64-71.

Emily, M, Mwalati, S, Robert, E, Musiega, D \& Maniagi, G 2014, 'Effect of corporate social responsibility on organisation performance; Banking industry kenya, Kakamega County', International Journal of Business and Management Invention, vol. 3, no. 4, pp. 37-51.

Fahria, T, Sahibzada, H \& Abdul, B 2016, 'The Impact of Environmental Reporting on Firms' Performance', International Journal of Accounting \& Business Management, vol. 4, no. 2, pp. 184-199.

Folajin, O, Ibitoye, O \& Dunsin, A 2014, 'Corporate social responsibility and organizational profitability: An empirical investigation of United Bank for Africa (UBA) Plc', International Journal of Academic Research in Business and Social Sciences, vol. 4, no. 8, pp. 205-214.

Gray, R, Collison, D \& Bebbington, J 1998, 'Environmental and social accounting and reporting', Centre for Social and Environmental Accounting Research, 1-9.

Güleryüz, F 2009, 'Value Based Management', viewed 2 March 2021, http://www.aso.org>

Guthrie, J \& Parker, L 1989, 'Corporate social reporting: a rebuttal of legitimacy theory', Accounting and Business Research, vol. 9, no. 76, pp. 343-352.

Ho, P \& Taylor, G 2013, 'Corporate governance and different types of voluntary disclosure', Pacific Accounting Review, vol. 25, no. 1, pp. 4-29.

Hossain, M \& Reaz, M 2007, 'The determinants and characteristics of voluntary disclosure by Indian banking companies', Corporate Social Responsibility and Environmental Management, vol. 14, no. 5, pp. 274288.

Ioannou, I \& Serafeim, G 2010, 'What drives corporate social performance?', Working Paper of International Evidence from Social, Environmental and Governance Sources, Harvard Business School, p. 311.

Jamali, D \& Mirshak, R 2007, 'Corporate social responsibility: Theory and practice in a developing country context', Journal of Business Ethics, vol. 72, pp. 243-262.

Jensen, M \& Meckling, W 1976, 'Theory of the firm: Managerial behavior, agency costs and ownership structure', Journal of Financial Economics, vol. 3, no. 4, pp. 305-360.

Justyna, F, Beata, Z \& Przemysław, G 2017, 'The relation between the CSR and the accounting information system data in Central and Eastern European (CEE) countries: The evidence of the Polish financial institutions', Accounting and Management Information Systems, vol. 16, no. 4, pp. 490-521. 
Karagiorgos, T 2010, 'Corporate social responsibility and financial performance: An empirical analysis on Greek companies', European Research Studies Journal, vol. 13, no. 4, pp. 85-108.

KPMG 2008, 'KPMG international survey of corporate responsibility reporting 2008', viewed 3 March 2021, $<$ http://www.kpmg.com>).

Lawrence, L, Thomas, T \& Yu, W 2017, 'sustainability reporting and firm value: Evidence from Singapore-listed companies', Sustainability, vol. 9, no. 11, pp. 1-12.

Lee, S, Seo, K \& Sharma, A 2013, 'Corporate social responsibility and firm performance in the airline industry: The moderation role of oil price', Tourism Management, vol. 38, pp. 20-30.

Lya, I, Badiya, Y \& Faiza, A 2015, 'Corporate social' responsibility (CSR) and the performance of First Bank Nigeria Plc, Adamawa State', Journal of Emerging Trend in Economics and Management Science, vol. 6, no. 6, pp. 377-389.

Marna, K, Charl, V \& Chris, S 2015, 'The influence of corporate social responsibility disclosure on share prices: Evidence from the United Kingdom', Pacific Accounting Review, vol. 27, no. 2, pp. 208-228.

Mohammed, I \& Samuel, A 2017, 'Role of macroeconomic variables on firms' performance: Evidence from the UK', Cogent Economics \& Finance,vol. 5, no. 1, 1-18.

Moskowitz, M 1972, 'Choosing socially responsible stocks', Business and Society Review, vol 1, pp. 71-75.

Nazari, J, Herremans, I \& Warsame, H 2015, 'Sustainability reporting: external motivators and internal facilitators', The International Journal of Business in Jensen, M \& Meckling, W 1976, 'Theory of the firm: managerial behavior, agency costs and ownership structure', Journal of Financial Economics, vol. 3 , no. 4, pp. 305-360.

Oba, V 2012, "The impact of corporate social responsibility on market value of quoted conglomerates in Nigeria', Ican Journal of Accounting and Finance, vol. 1, no. 3, pp. 64-70.

Odetayo, T, Adeyemi, A \& Sajuyigbe, A 2014, 'Impact of Corporate Social Responsibility on Profitability of Nigeria Banks', International Journal of Academic Research in Business and Social Sciences, vol. 4, no. 8, pp. 252-263.

Ohlson, J 1995, 'Earnings, Book values, and dividends in equity valuation', Contemporary Accounting Research, vol. 11, no. 2, pp. 661-687.

Okafor, U, Oji, R \& Daferighe, E 2020, 'Environmental and social accounting practices, and financial performance of cement companies: empirical evidence from Nigeria', European Journal of Business and Management, vol. 12, no. 20, pp. 60-72.

Olaroyeke, R \& Tabitha, N 2015, 'Effect of corporate social responsibility on performance of manufacturing companies in Nigeria', International Journal of Current Advanced Research, vol. 4, no. 8, pp. 228-233.

Oliveira, L, Rodrigues, L \& Craig, R 2010, 'Intellectual Capital reporting in sustainability reports', Journal of Intellectual Capital, vol. 11, no. 4, pp. 575-594.

Oliver, C 1991, 'strategic responses to institutional processes', Academy of Management Review, Peloza, J, Loock, M, Cerruti, J \& Muyot, M 2012, 'Sustainability: how stakeholder perceptions differ from corporate reality’, California Management Review,vol. 55, no. 1, pp. 74-97.

Osazuwa, N, Francis, O \& Izedonmi, F 2013, 'Corporate attributes and environmental disclosures of Nigerian quoted firms: An empirical analysis', Research Journal of Social Science \& Management, vol. 3, no. 6,pp. 150- 158.

Otuo, S \& Abraham, A 2017, 'Corporate social responsibility and firm performance of Ghanaian SMEs: Mediating role of access to capital and firm reputation', Journal of Global Responsibility, vol. 8, no. 1, pp. 47-62.

Power, M 1991, 'Auditing and environmental expertise: Between protest and professionalism', Accounting, Auditing \& Accountability Journal, vol. 4, no. 3, pp. $30-42$.

Rahman, N, Jauhari, H \& Roslan, N 2013, 'An Empirical Examination of the Relationship between Environmental Disclosure and Financial Performance in Malaysia', Journal of Contemporary Issues and Thought, vol. 3, pp. 77-92.

Reverte, C 2009, 'Determinants of corporate social responsibility disclosure ratings by Spanish listed firms', Journal of Business Ethics, vol. 88, no. 2, pp. 351-366.

Shamil, M, Shaikh, J, Ho, P \& Krishnan, A 2014, 'The influence of board characteristics on sustainability reporting: Empirical evidence from Sri Lankan firms', Asian Review of Accounting, vol. 22, no. 2, pp. 78-97.

Siregar, S \& Bachtiar, Y 2010, 'Corporate social reporting: empirical evidence from Indonesia stock exchange', International Journal of Islamic and Middle Eastern Finance and Management, vol 3, no. 8, pp. 241-252.

Slaper, T \& Hall, T 2011, 'The Triple Bottom Line: What Is It and How Does It Work?', viewed 18 February 2021, < $\underline{\text { https://www.ibrc.indiana.edu/ibr/2011/spring/article2.html }>\text {. }}$

Suchman, M 1995, 'Managing Legitimacy: Strategic and Institutional Approaches', Academy of Management Journal, vol. 20, no. 3, pp. 571 - 610 . 
Unerman, J \& O'Dwyer, B 2007, 'The Business Case for Regulation of Corporate Social Responsibility and Accountability', Accounting Forum, vol. 31, no. 4, pp. 332-353.

Uyar, A \& Kılıç, M 2012, 'Value relevance of voluntary disclosure: evidence from Turkish firms', Journal of Intellectual Capital, vol 13, no. 3, pp. 363-376.

VanMarewijk, M 2003, 'Concepts and definitions of CSR and corporate sustainability: between agency and communication', Journal of Business Ethics, vol. 44, no. 2/3, pp. 95-105.

Wan, S, Mahmoud, K \& Arkan, W 2014, 'Does corporate social responsibility lead to improvement in firm financial performance: Evidence from Malaysia?', Internal Tonal Journal of Economics and Finance, vol. 6, no. 3, pp. 126-138.

Wang, Q, Dou, J \& Jia, S 2016, 'A meta-analytic review of corporate social responsibility and corporate financial performance: The moderating effect of contextual factors', Business \& Society, vol. 55, no. 8, pp. 1083-1121.

World Business Council for Sustainable Development 1990, 'Corporate social responsibility: Meeting changing expectations', World Business Council for Sustainable Development, Switzerland, p. 237.

\section{Appendix 1}

\section{Population of the Study}

Quoted Firms in the Oil and Gas Sector

$11 \mathrm{Plc}$

Anino International Plc

Capital Oil Plc

Conoil Plc

Eterna Plc

Forte Oil Plc

Japaul Oil and Maritime Services

MRS Oil Nigeria Plc

Oando Plc

Rak Unity Petroleum Company Plc

Seplat Petroleum Development Company Plc

Total Nigeria Plc

\section{Appendix II}

Table 4.1 Raw Panel Data for Analysis

COMPANY

FORTE OIL

PLC

PLC

MRS OIL

NIGERIA

PLC.

$\begin{array}{ccc}2007 & 9.34 & 7.26 \\ 2008 & 8.83 & 6.47 \\ 2009 & 53.47 & -8.48 \\ 2010 & 38.58 & -2.5 \\ 2011 & 5.40 & -14.43 \\ 2012 & 6.95 & 0.93 \\ 2013 & 38.96 & 4.32 \\ 2014 & 40.59 & 2.20 \\ 2015 & 42.37 & 4.13 \\ 2016 & 33.06 & 1.99 \\ 2017 & 42.18 & 2.85 \\ 2018 & 48.50 & 1.46 \\ & & \\ 2007 & 15.93 & 7.71 \\ 2008 & 7.54 & -0.89 \\ 2009 & 11.68 & 4.14 \\ 2010 & 72.95 & 7.27\end{array}$

E

EPC

CETC

CHRC

P (DEPENDENT)

0
870,000
$2,740,000$
100,000
250,000
$4,100,000$
$1,000,000$
$3,250,000$
$2,001,050$
$3,263,600$
$4,873,438$

150,000

0

70,000

70,000

50,000

100,000

$1,000,000$

$3,000,000$

$5,885,500$

0

0

715,000

7.71

$-0.89$

4.14

7.27

0
0
$13,000,000$
$7,100,000$

0
0
0
100,000

100,000

207.00

$0 \quad 293.98$

$120,000 \quad 33.51$

$250,000 \quad 21.9$

$50,000 \quad 11.6$

$0 \quad 7.73$

$0 \quad 97.75$

$488,091 \quad 227.90$

$1,000,000 \quad 330.00$

$0 \quad 93.54$

$0 \quad 43.48$

$0 \quad 28.70$

160.00

168.31

69.79

66.56 


\begin{tabular}{|c|c|c|c|c|c|c|c|}
\hline & 2011 & 74.76 & 2.42 & 400,000 & 600,000 & 200,000 & 59.00 \\
\hline & 2012 & 75.02 & 0.81 & 300,000 & $1,800,000$ & 100,000 & 23.76 \\
\hline & 2013 & 77.28 & 2.50 & $1,200,000$ & 990,000 & 0 & 54.44 \\
\hline & 2014 & 79.60 & 2.94 & 700,000 & $11,221,500$ & 368,500 & 53.20 \\
\hline & 2015 & 82.59 & 3.68 & $3,950,000$ & $1,423,500$ & 0 & 49.66 \\
\hline & 2016 & 87.26 & 5.77 & 300,000 & 168,500 & 300,000 & 43.24 \\
\hline & 2017 & 90.99 & 4.54 & $1,271,371$ & $8,418,192$ & 0 & 27.46 \\
\hline & 2018 & 67.98 & -4.15 & $1,698,792$ & $2,379,750$ & 100,000 & 25.70 \\
\hline \multirow[t]{12}{*}{ OANDO PLC } & 2007 & 62.88 & 7.51 & $5,595,122$ & $17,219,535$ & 0 & 122.60 \\
\hline & 2008 & 49.6 & 9.22 & $30,102,755$ & $6,126,640$ & 250,000 & 82.74 \\
\hline & 2009 & 64.14 & 11.32 & $165,277,421$ & $35,330,383$ & $7,350,970$ & 93.99 \\
\hline & 2010 & 52.59 & 11.32 & $12,619,800$ & $7,248,886$ & $52,440,305$ & 66.00 \\
\hline & 2011 & 40.79 & 8.29 & $34,167,800$ & $251,956,725$ & $78,689,709$ & 22.00 \\
\hline & 2012 & 46.33 & 1.26 & $18,010,169$ & $109,665,938$ & $42,217,795$ & 12.35 \\
\hline & 2013 & 11.68 & 0.23 & $2,762,814$ & $126,568,924$ & 970,500 & 24.25 \\
\hline & 2014 & 3.12 & -20.76 & $24,586,624$ & $129,467,950$ & $8,719,795$ & 16.11 \\
\hline & 2015 & 3.84 & -4.22 & $3,490,856$ & $86,739,621$ & $3,610,000$ & 5.90 \\
\hline & 2016 & 1.02 & 0.30 & $120,606,411$ & $24,617,277$ & 0 & 4.55 \\
\hline & 2017 & 21.19 & 1.13 & $250,000,000$ & 0 & 0 & 5.99 \\
\hline & 2018 & 22.29 & 1.97 & $435,000,000$ & 0 & 0 & 5.00 \\
\hline \multirow[t]{12}{*}{$\begin{array}{c}11 \text { PLC } \\
\text { (MOBIL) }\end{array}$} & 2007 & 7.48 & 4.71 & 0 & 0 & 0 & 180.00 \\
\hline & 2008 & 9.44 & 6.22 & $1,650,000$ & 750,000 & 500,000 & 331.19 \\
\hline & 2009 & 40.52 & 9.46 & $1,096,500$ & 494,500 & 559,000 & 98.80 \\
\hline & 2010 & 19.86 & 12.93 & $2,250,000$ & $1,000,000$ & $1,150,000$ & 141.00 \\
\hline & 2011 & 14.97 & 12.14 & $4,450,000$ & $2,700,000$ & $2,100,000$ & 133.91 \\
\hline & 2012 & 18.28 & 8.56 & $1,750,000$ & $1,250,000$ & $4,500,000$ & 109.25 \\
\hline & 2013 & 26.45 & 10.35 & $2,500,000$ & $2,050,000$ & $3,500,000$ & 118.60 \\
\hline & 2014 & 37.58 & 17.73 & $4,100,000$ & $3,000,000$ & $1,000,000$ & 158.00 \\
\hline & 2015 & 42.61 & 13.51 & $3,500,000$ & $4,500,000$ & $2,000,000$ & 160.00 \\
\hline & 2016 & 59.51 & 22.61 & $12,350,000$ & 500,000 & $3,000,000$ & 290.00 \\
\hline & 2017 & 75.87 & 22.61 & $1,850,000$ & 0 & 775,000 & 194.60 \\
\hline & 2018 & 93.66 & $2,587.00$ & $3,750,000$ & $10,000,000$ & 0 & 185.50 \\
\hline \multicolumn{8}{|l|}{$\begin{array}{c}\text { TOTAL } \\
\text { NIGERIA }\end{array}$} \\
\hline \multirow[t]{12}{*}{ PLC } & 2007 & 18.69 & 9.59 & $3,200,000$ & 200,000 & 800,000 & 180.00 \\
\hline & 2008 & 21.22 & 12.94 & 0 & 0 & 0 & 203.69 \\
\hline & 2009 & 20.57 & 11.69 & $2,800,000$ & 800,000 & 400,000 & 149.00 \\
\hline & 2010 & 26.30 & 16.01 & $2,800,000$ & 800,000 & 400,000 & 234.00 \\
\hline & 2011 & 29.53 & 11.23 & $3,400,000$ & 400,000 & 200,000 & 188.10 \\
\hline & 2012 & 33.29 & 13.76 & $3,200,000$ & 600,000 & 200,000 & 120.57 \\
\hline & 2013 & 39.00 & 15.71 & $8,837,864$ & $12,300,000$ & $13,208,650$ & 170.00 \\
\hline & 2014 & 46.92 & 15.58 & $9,400,000$ & $26,699,500$ & $20,329,451$ & 142.50 \\
\hline & 2015 & 47.84 & 11.92 & $15,865,605$ & $25,819,785$ & $13,250,000$ & 147.01 \\
\hline & 2016 & 69.42 & 43.58 & $95,067,767$ & $32,000,695$ & $5,054,080$ & 299.00 \\
\hline & 2017 & 84.02 & 23.62 & $53,010,127$ & $66,426,056$ & $12,855,674$ & 229.95 \\
\hline & 2018 & 90.51 & 23.45 & $40,292,152$ & $22,146,394$ & $18,482,707$ & 203.00 \\
\hline
\end{tabular}

